Eva Fida Zumaroh, I Dewa Ketut Sastra Widana, Ni Luh Muliani. Penerapan model pembelajaran kooperatif tipe teams games tournament (TGT) pada pembelajaran kimia untuk meningkatkan motivasi dan hasil belajar siswa. Jurnal Pendidikan Kimia Indonesia. Volume 1 Nomor 12017

\title{
PENERAPAN MODEL PEMBELAJARAN KOOPERATIF TIPE TEAMS GAMES TOURNAMENT (TGT) PADA PEMBELAJARAN KIMIA UNTUK MENINGKATKAN MOTIVASI DAN HASIL BELAJAR SISWA
}

\author{
Eva Fida Zumaroh, S.Pd' ${ }^{1}$ I Dewa Ketut Sastra Widana ${ }^{2}$, Ni Luh Muliani ${ }^{3}$ \\ ${ }^{1}$ Universitas Pendidikan Ganesha \\ 2Universitas Pendidikan Ganesha \\ ${ }^{3}$ SMA Negeri 3 Singaraja
}

\begin{abstract}
Abstrak
Penelitian ini bertujuan untuk mengetahui peningkatan motivasi belajar dan hasil belajar siswa terhadap penerapan model pembelajaran kooperatif tipe Teams Games Tournament (TGT). Penelitian ini merupakan penelitian tindakan kelas (Classroom Action Research). Penelitian dilaksanakan pada pada tanggal 5 Oktober - 22 Oktober 2016 di kelas XII MIPA 3 SMA Negeri 3 Singaraja dengan jumlah siswa 25 . Teknik pengambilan data mengunakan observasi, pemberian angket, dan test uji kompetensi kognitif. Instrumen yang digunakan adalah lembar observasi motivasi, lembar angket motivasi dan lembar soal test uji kompetensi kognitif. Hasil penelitian menunjukkan bahwa model pembelajaran kooperatif tipe Teams Games Tournament (TGT) dapat meningkatkan motivasi dan hasil belajar siswa. Hasil observasi motivasi siswa pada siklus I yaitu 68\% siswa memiliki motivasi belajar yang tinggi dan meningkat pada siklus II sebesar 32\% menjadi $100 \%$ siswa sudah menunjukkan motivasi yang tinggi. Data angket motivasi siswa pada siklus I yaitu $40 \%$ siswa memiliki motivasi yang tinggi dan meningkat pada siklus II menjadi 72\% siswa. Hasil belajar siswa siklus I, 64\% siswa tuntas belajar dan $16 \%$ siswa belum tuntas belajar dan terjadi peningkatan pada siklus II sebesar $20 \%$ menjadi $84 \%$ siswa tuntas belajar dan $16 \%$ siswa belum tuntas belajar.
\end{abstract}

Kata-kata kunci:

Kooperatif tipe TGT,

Motivasi Belajar Siswa, Hasil Belajar

\section{Pendahuluan}

Belajar dalam pendidikan dipandang sebagai usaha sadar dan disengaja yang dirancang dengan baik untuk mencapai tujuan pendidikan. Proses pembelajaran pada hakekatnya diupayakan agar peserta didik dapat mengembangkan aktivitas dan kreativitasnya melalui berbagai interaksi dan pengalaman belajar. Hakikat lain dari pembelajaran adalah perencanaan atau perancangan yang disiapkan guru dalam upaya membelajarkan siswa. Oleh karena itu dalam pembelajaran, diharapkan desain atau rancangan yang disiapkan tidak hanya membuat siswa berinteraksi dengan guru sebagai salah satu sumber belajar, tetapi juga dengan keseluruhan sumber belajar lain. Sumber belajar lain dalam bentuk pengajaran melalui media, metode, maupun pendekatan dalam pembelajaran (Sudjana, 2007).

Pembelajaran yang baik memungkinkan siswa tidak hanya berinteraksi dengan guru namun juga dengan lingkungan, sehingga dalam proses pembelajarannya siswa tidak hanya sekedar menghafal sejumlah fakta atau informasi, akan tetapi terjadi peristiwa mental dan proses berpengalaman. Sesuai dengan peraturan pemerintah No. 32 Tahun 2013 pasal 19 dikatakan bahwa "proses pembelajaran pada satuan pendidikan diselenggarakan secara interaktif, inspiratif, menyenangkan, menantang, memotivasi peserta didik untuk berpartisipasi aktif, serta memberikan ruang yang cukup bagi prakarsa, kreativitas dan kemandirian sesuai dengan bakat, minat dan perkembangan fisik serta psikologis peserta didik". Hal ini memperjelas bahwa rencana pembelajaran yang didesain oleh guru harus berorientasi pada kegiatan siswa yang menyenangkan untuk meningkatkan potensi otak.

Saat ini pemerintah telah menetapkan kurikulum 2013 yang dapat dijadikan acuan bagi guru dalam menjalankan tugas dan fungsinya dengan baik. Berdasarkan hasil observasi yang dilakukan selama proses kegiatan belajar mengajar dan wawancara dengan guru bidang studi kimia, guru telah menggunakan model 
pembelajaran yang berorientasi pada kegiatan siswa sesuai dengan kurikulum yang berlaku. Guru bidang studi kimia pun telah menggunakan media pembelajaran yang sesuai dengan model pembelajaran untuk membantu kelancaran proses pembelajaran yang mengaktifkan peran siswa. Namun kenyataan yang terjadi dilapangan, walaupun guru telah menggunakan model pembelajaran yang melibatkan siswa tetapi tidak semua siswa aktif dalam proses pembelajaran. Pada proses pembelajaran, hanya beberapa siswa yang aktif sedangkan sebagian besar siswa masih saja menunjukkan kepasifan dalam belajar. Hal itu dapat terlihat ketika proses mengasosiasi data dengan mengerjakan LKS yang telah diberikan. Dalam kerja kelompok tersebut, hanya beberapa siswa yang aktif mencari jawaban namun siswa yang lainnya hanya diam. Begitu pula ketika proses diskusi terjadi, siswa yang aktif maju ke depan mengungkapkan gagasan dan menanggapi jawaban hanya beberapa orang siswa. Berdasarkan angket motivasi yang telah disebar, salah satu fakor yang menyebabkan siswa pasif dalam pembelajaran kimia adalah masih rendahnya motivasi belajar yang ada di dalam diri siswa. Hasil angket motivasi prapenelitian menunjukkan bahwa $45 \%$ siswa mempunyai motivasi belajar yang tinggi, $40 \%$ siswa mempunyai motivasi belajar sedang dan sebanyak 15\% siswa mempunyai motivasi yang rendah. Motivasi belajar yang rendah ini dikarenakan presepsi awal siswa terhadap mata pelajaran kimia yang menganggap bahwa kimia merupakan mata pelajaran yang sulit dipahami dan pengemasan pembelajaran kimia yang kurang menarik perhatian siswa.

Motivasi belajar siswa yang rendah ternyata berdampak pada rendahnya hasil belajar kimia siswa. Hal ini sesuai dengan data hasil belajar siswa yang diperoleh dari guru bidang studi kimia, pada kelas XI MIPA 3 tahun ajaran 2015/2016 ssebagian siswa belum mencapai kriteria ketuntasan minimal (KKM) yaitu 78. Nilai rata - rata siswa sebesar 83 dengan persentase nilai di atas KKM yaitu 73\% dan persentase nilai di bawah KKM yaitu $27 \%$. Apabila $80 \%$ dari jumlah siswa yang mengikuti proses belajar atau mencapai taraf keberhasilan minimal, maka proses belajar mengajar berikutnya dapat membahas pokok bahasan baru dan hendaknya bersifat perbaikan. Dalam hal ini dapat dikatakan bahwa proses belajar mengajar berikutnya seharusnya belum dapat melanjutkan pokok bahasan baru dan guru hendaknya melakukan perbaikan.

Berbagai upaya inovasi dalam pengemasan materi kimia diperlukan untuk meningkatkan motivasi belajar siswa terhadap kimia, salah satunya mealui penggunaan metode pembelajaran yang bervariasi, menyenangkan dan menarik perhatian. Salah satu metode yang dapat digunakan adalah model pembelajaran Teams Games Tournament (TGT). Model pembelajaran Teams Games Tournament (TGT). TGT menambahkan dimensi kegembiraan dengan mengganti kuis pada pembelajaran menjadi permainan atau tournament. Menurut Huda (2011: 117) dengan TGT siswa akan menikmati bagaimana suasana turnamen, dan karena mereka berkompetisi dengan kelompok yang memiliki kemampuan setara, membuat TGT terasa lebih fair dibandingkan kompetisi dalam pembelajaran tradisional pada umumnya. Sehingga, TGT merupakan salah satu model yang dapat menarik perhatian serta menyebabkan suasana belajar menjadi lebih menyenangkan sehingga siswa dapat termotivasi untuk mempelajari kimia.

Berdasarkan penelitian yang telah dilakukan tentang penerapan model pembelajaran kooperatif tipe Teams Games Tournament (TGT) dapat meningkatkan motivasi dan hasil belajar belajar IPA di SMP N I Ngaglik Sleman. Peningkatkan motivasi siswa ditunjukkan dengan adanya kenaikan persentase motivasi belajar siswa dari siklus I ke siklus II sebesar 10,7\%. Sementara itu, peningkatan hasil belajar siswa juga ditandai dengan adanya peningkatan nilai rata - rata posttest dari siklus 1 ke siklus II sebesar 15,6 poin.

Berdasarkan hasil observasi, wawancara, angket siswa dan penelitian terkait yang telah dilakukan sebelumnya tentang manfaat menggunakan metode permainan dalam meningkatkan motivasi dan hasil belajar siswa maka peneliti ingin melakukan penelitian tindakan kelas dengan menerapkan metode yang sama yaitu model pembelajaran kooperatif tipe Teams Games Tournament (TGT) pada pembelajaran kimia untuk meningkatkan motivasi dan hasil belajar siswa kelas XII MIPA 3 di SMA Negeri 3 Singaraja tahun Ajaran 2016/2017.

\section{Metode}

Penelitian yang dilakukan adalah jenis penelitian tindakan kelas (Classroom Action Research) karena penelitian ini bertujuan menganalisis atau memecahkan suatu masalah nyata dalam bidang pendidikan. Penelitian ini termasuk penelitian tindakan kelas. Subjek dalam penelitian ini adalah siswa kelas MIPA 3 SMA N 3 Singaraja yang berjumlah 25 siswa. Objek penelitian merupakan permasalahan yang diteliti. Objek penelitian ini adalah penerapan model pembelajaran kooperatif tipe Teams Games Tournament. Menurut model Kemmis dan M.C Taggart (Sugiarti, 1997: 6), bahwa 
penelitian tindakan kelas dilaksanakan berupa proses pengkajian berdaur yang terdiri dari 4 tahap yaitu rancangan, pelaksanaan tindakan, pengamatan, dan refleksi. (1). Rancangan. Sebelum penelitian dilaksanakan, terlebih dahulu peneliti harus merencanakan dan menentukan hal-hal yang perlu dalam penelitian. Hal ini dilakukan agar penelitian yang dilakukan berjalan dengan lancar dan sesuai dengan apa yang diharapkan oleh peneliti. Hal yang harus dipersiapkan antara lain menentukan pokok bahasan, membuat program rencana pembelajaran, menyiapkan ide permainan, menyiapkan angket motivasi, membuat LKS, dan membuat lembar butir tes. (2) Pelaksanaan Tindakan. Tahap pelaksanaan merupakan implementasi atau penerapan isi rancangan, yaitu penerapan penelitian tindakan pada kelas. Dalam pelaksanaan tahap ini guru melaksanakan dan berusaha menaati apa yang ada dalam rancangan pembelajaran. Sehingga apa yang ada dalam rancangan pembelajaran sesuai dengan apa yang dilakukan oleh guru. (3). Pengamatan dan evaluasi Pada tahap pengamatan dilakukan oleh pengamat. Pelaksanaan tahap ini dilakukan bersamaan dengan tahap pelaksanaan tindakan. Ketika peneliti sedang melakukan tahap pelaksanaan tindakan maka peneliti tidak dapat melakukan tahap pengamatan sehingga peneliti membutuhkan pengamat dari pihak lain. Dalam penelitian ini mengunakan pengamat untuk mengamati aktivitas siswa dan mengamati aktivitas dari guru. Dalam hal ini pengamat diharapkan obyektif saat melakukan pengamatan sehingga tidak mempengaruhi hasil pengamatan. (4) Refleksi. Pada tahap yang keempat ini merupakan kegiatan untuk mengemukakan kembali apa yang sudah dilakukan dalam penelitian. Kegiatan ini merupakan kegiatan akhir dalam penelitian. Pada tahap ini dilakukan diskusi antara pengamat dengan guru untuk mengetahui apa saja yang telah dilakukan oleh guru dalam proses pembelajaran. Sehingga setelah tahap ini diharapkan akan adanya perbaikan pada proses pembelajaran.

Hasil

Pada bagian ini menyajikan data hasil penelitian, analisis data beserta pembahasan dari penelitian yang telah dilaksanakan di SMA Negeri 3 Singaraja. Pengambilan data dalam rangka penelitian ini dilakukan pada tanggal 5 Oktober sampai 22 Oktober Tahun 2016. Data yang telah diperoleh meliputi data tentang motivasi belajar siswa dan hasil belajar siswa. Siklus I dilaksanakan selama tiga kali pertemuan dengan dua kali pertemuan pembahasan materi dan pertemuan ketiga dengan melakukan uji tes kompetensi kognitif. Tindakan yang dilakukan pada siklus 1, yaitu dengan menerapkan model pembelajaran kooperatif tipe Teams Games Tournament (TGT) dengan sub pokok bahasan gas mulia dan halogen. Masing - masing sub pokok bahasan dilaksanakan selama 2 x 45 menit. Untuk mendukung efektivitas dan efisiensi pembelajaran, maka disusun lembar kerja siswa (LKS) dan didistribusikan kepada siswa sebelum proses pembelajaran berlangsung. Kegiatan pembelajaran menggunakan model pembelajaran kooperatif tipe Teams Games Tournament (TGT) berpedoman pada langkah - langkah kegiatan pembelajaran yang telah tersusun dalam rancangan pelaksanaan pembelajaran (RPP) yang mencakup KI, KD, indikator, materi pembelajaran dan metode pembelajaran yang tertuang pada RPP yang dapat dilihat pada lampiran I. Data yang didapat dari hasil penelitian tindakan kelas penerapan model pembelajaran kooperatif tipe Teams Games Tournament yaitu data tentang motivasi belajar siswa dan hasil belajar siswa yang dapat dijabarkan sebagai berikut :

\section{Hasil Motivasi Belajar Siswa}

Data hasil observasi siswa kelas XII MIPA 3 SMA Negeri 3 Singaraja yang berjumlah 25 siswa siklus I didapatkan melalui hasil pengamatan yang dilakukan oleh empat orang pengamat selama dua kali pertemuan. Tiga orang pengamat masing - masing mengawasi satu kelompok belajar siswa yang beranggotakan 5 siswa dan satu pengamat lainnya mengamati dua kelompok belajar. Penilaian motivasi siswa terdiri dari tujuh indikator yaitu tekun menghadapi tugas, ulet menghadapi kesulitan, menunjukan minat terhadap bermacam-macam masalah, lebih senang bekerja mandiri, dapat mempertahankan pendapatnya, tidak mudah melepaskan hal yang diyakini itu, dan senang memecahkan masalah soal-soal. Ketujuh indikator motivasi tersebut dirinci lebih detail menjadi 17 item pengamatan. Ketujuh belas item pengamatan tersebut dinilai pengamat berdasarkan rubrik pengamatan yang ada. Kisi - kisi lembar observasi motivasi belajar siswa dan lembar observasi motivasi belajar siswa berturut - turut dapat dilihat pada lampiran 4 dan lampiran 5. Hasil akhir motivasi masing - masing siswa didapat dari persentase nilai rata - rata ketujuh belas item yang kemudian dikategorikan dengan kriteria tinggi, sedang, dan rendah.

Berdasarkan tabel 4.2, dapat terlihat bahwa pada pertemuan pertama sebesar $48 \%$ atau 12 siswa sudah menunjukkan motivasi yang tinggi dalam mengikuti proses pembelajaran dan meningkat $40 \%$ menjadi $88 \%$ atau 22 siswa 
pada pertemuan kedua, sedangkan 52\% atau 13 siswa pada pertemuan pertama menunjukkan motivasi yang sedang dan menurun menjadi $12 \%$ atau 3 siswa pada pertemuan kedua. Secara klasikal, pada siklus I rata - rata dari siswa dengan motivasi kategori tinggi yaitu sebesar $68 \%$.

Pada penelitian ini, indikator keberhasilan yang dipakai adalah ketika motivasi siswa dengan kriteria tinggi mencapai $80 \%$ atau lebih. Berdasarkan hasil observasi motivasi siswa, rata motivasi siswa dengan kriteria tinggi hanya sebesar $68 \%$ atau kurang dari $80 \%$, sehingga pada sikus satu dikatakan belum berhasil dan perlu dilakukan perbaikan pada siklus ke dua untuk dapat mencapai target keberhasilan. Data pendukung tentang motivasi siswa juga dapat dilihat dari lembar angket motivasi siswa yang diisi oleh siswa. Penilaian motivasi siswa yang terdapat pada lembar angket terdiri dari tujuh indikator sesuai pada lembar observasi motivasi siswa yaitu tekun menghadapi tugas, ulet menghadapi kesulitan, menunjukan minat terhadap bermacam-macam masalah, lebih senang bekerja mandiri, dapat mempertahankan pendapatnya, tidak mudah melepaskan hal yang diyakini itu, dan senang memecahkan masalah soal-soal. Ketujuh indikator tersebut kemudian dijabarkan menjadi 40 item. Kisi - kisi lembar angket motivasi belajar siswa dan lembar angket motivasi siswa berturut - turut dapat dilihat pada lampiran 2 dan lampiran 3. Lembar angket motivasi belajar siklus I didistribusikan kepada siswa setelah melaksanakan tes uji kompetensi kognitif I. Hasil akhir motivasi masing - masing siswa didapat dari persentase nilai rata - rata keempat puluh item yang kemudian dikategorikan dengan kriteria tinggi, sedang, dan rendah

Berdasarkan angket motivasi sebanyak 10 siswa sudah memiliki motivasi tinggi dan 15 siswa masih memiliki motivasi dengan kriteria sedang. Berdasarkan data tersebut, untuk lebih jelasnya dapat dilihat dari grafik motivasi belajar siswa kelas XII MIPA 3 SMA Negeri 3 Singaraja.

\section{Motivasi Tinggi Motivasi Rend}

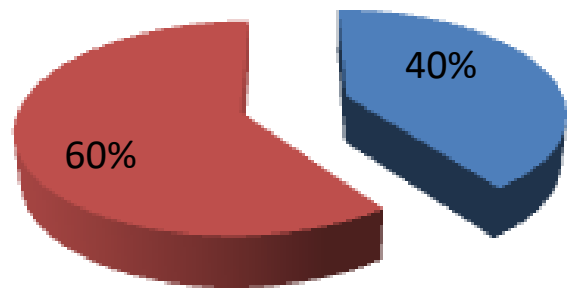

Gambar 4.1 Motivasi Belajar Siswa

Berdasarkan grafik 4.3, dapat terlihat bahwa $60 \%$ siswa sudah memiliki motivasi belajar dengan kriteria tinggi dan 40\% siswa masih memliki motivasi belajar dengan kriteria rendah.

\section{Hasil Belajar Siklus I}

Selain data motivasi belajar siswa kelas XII MIPA 3 SMA Negeri 3 Singaraja diperoleh juga data hasil belajar siswa setelah diterapkannya model pembelajaran kooperatif tipe Teams Games Tournament. Data hasil belajar siswa didapatkan dari nilai uji tes kompetensi kognitif menggunakan lembar soal tes kompetensi kognitif. Kisi - kisi uji test kompetensi kognitif dan lembar soal tes kompetensi kognitif berturut - turut dapat dilihat pada lampiran 5 dan lampiran 6. Data hasil belajar siswa secara keseluruhan dapat dilihat pada lampiran 10. Rangkuman data hasil belajar siswa kelas XII MIPA 3 SMA Negeri 3 Singaraja dengan penerapan metode pembelajaran kooperatif tipe Teams Games Tournament pada siklus I bias dilihat pada Tabel 1 berikut :

Tabel 1 Hasil Belajar Siswa Siklus 1

\begin{tabular}{ccccc}
\hline Rentang Nilai & Perdikat & $\begin{array}{c}\text { Jumlah } \\
\text { siswa }\end{array}$ & Presentase & Ketuntasan \\
\hline $91-100$ & A (Sangat Baik) & 3 & $12 \%$ & Tuntas \\
$81-90$ & B (Baik) & 5 & $20 \%$ & Tuntas \\
$78-80$ & C (Cukup) & 8 & $32 \%$ & Tuntas \\
$<78$ & D (Kurang) & 9 & $36 \%$ & Belum Tutas \\
\hline
\end{tabular}

Berdasarkan tabel 1 terlihat bahwa sebesar 36\% siswa atau sebanyak 9 siswa belum mencapai ketuntasan karena belum mencapai nilai KKM sekolah yaitu sebesar 78 sedangkan sebesar 64\% siswa atau sebanyak 16 siswa sudah tuntas belajar dengan 3 siswa mendapat nilai dengan predikat $A$ atau sangat baik dengan rentangan nilai 91-100, 2 siswa mendapat nilai dengan predikat $\mathrm{B}$ atau baik dengan rentangan nilai 81-90 dan 8 siswa mendapat nilai dengan predikat $\mathrm{C}$ atau cukup dengan rentangan nilai yang didapat $78-80$.

Pada penelitian ini, indikator keberhasilan yang dipakai adalah ketika ketuntasan belajar klasikal mencapai $80 \%$ atau lebih. Berdasarkan hasil uji kompetensi kognitif siklus I yang telah dilakukan, ketuntasan klasikal pada kelas XII MIPA 3 hanyalah sebesar 64\% 
atau kurang dari 80\%, sehingga pada sikus satu dikatakan belum berhasil dan perlu dilakukan perbaikan pada siklus ke dua untuk dapat mencapai target keberhasilan.

\section{Hasil Belajar Siklus II}

Data hasil belajar siswa siklus II didapatkan dari nilai uji tes kompetensi kognitif menggunakan lembar soal tes kompetensi kognitif. Kisi - kisi uji test kompetensi kognitif dan lembar soal tes kompetensi kognitif berturut - turut dapat dilihat pada lampiran 5 dan lampiran 6. Data hasil belajar siswa secara keseluruhan dapat dilihat pada lampiran 10 . Rangkuman data hasil belajar siswa kelas XII MIPA 3 SMA Negeri 3 Singaraja dengan penerapan metode pembelajaran kooperatif tipe Teams Games Tournament pada siklus II tersedia pada Tabel 2 berikut :

Tabel 2 Hasil Belajar Siswa Siklus II

\begin{tabular}{ccccc}
\hline Rentang Nilai & Kategori Nilai & Jumlah siswa & Presentase & Ketuntasan \\
\hline $91-100$ & A (Sangat Baik) & 5 & $20 \%$ & Tuntas \\
$81-90$ & B (Baik) & 5 & $20 \%$ & Tuntas \\
$78-80$ & C (Cukup) & 11 & $44 \%$ & Tuntas \\
$<78$ & D (Kurang) & 4 & $16 \%$ & Belum Tuntas \\
\hline
\end{tabular}

Berdasarkan tabel 2 terlihat bahwa pada siklus II, 5 siswa mendapat nilai dengan predikat A atau sangat baik dengan rentangan nilai 91100,5 siswa mendapat nilai dengan predikat B atau baik dengan rentangan nilai 81-90 dan 11 siswa mendapat nilai dengan predikat $\mathrm{C}$ atau cukup dengan rentangan nilai yang didapat 78 80. Sehingga 21 siswa atau $84 \%$ siswa kelas XII MIPA 3 telah mencapai ketuntasan belajar. Sedangkan Jumlah siswa yang tidak tuntas belajar 4 siswa atau sebesar 16\%. Siswa yang belum mencapai ketuntasan ini karena belum mencapai nilai KKM sekolah yaitu sebesar 78 .

Pada penelitian ini, indikator keberhasilan yang dipakai adalah ketika ketuntasan belajar klasikal mencapai $80 \%$ atau lebih. Berdasarkan hasil uji kompetensi kognitif siklus II yang telah dilakukan, ketuntasan klasikal pada kelas XII MIPA 3 sebesar $84 \%$ atau sudah lebih dari $80 \%$, sehingga pada sikus II dapat dikatakan bahwa penelitian telah berhasil.

\section{Pembahasan}

Berdasarkan hasil motivasi belajar pada siklus I dan siklus II yang didapatkan melalui observasi dan angket motivasi, terlihat terjadi peningkatan motivasi belajar siswa dimana pada siklus satu pada pertemuan pertama sebesar $48 \%$ atau 12 siswa menunjukkan motivasi yang tinggi dalam mengikuti proses pembelajaran dan meningkat $40 \%$ menjadi $88 \%$ atau 22 siswa pada pertemuan kedua. Secara klasikal, pada siklus I rata - rata siswa dengan motivasi kategori tinggi yaitu sebesar $68 \%$ dan meningkat pada siklus II sebanyak 32\% menjadi $100 \%$ siswa atau semua siswa sudah menunjukkan motivasi yang tinggi.

Peningkatan motivasi belajar siswa juga dapat dilihat dari data angket motivasi siswa. Angket motivasi siswa dibuat berdasarkan kisi kisi yang sama seperti pada lembar observasi motivasi siswa. Pada siklus I, siswa dengan motivasi tinggi hanya sebesar $40 \%$ siswa atau sebanyak 10 siswa kemudian meningkat pada siklus II menjadi 72\% atau sebanyak 18 siswa.

Peningkatan motivasi hasil belajar ini dikarenakan siswa termotivasi dengan adanya turnamen yang diadakan pada pelaksanaan model pembelajaran kooperatif tipe Teams Games Tournament. Pada akhir pelaksanaan turnamen ini kelompok pemenang akan mendapatkan poin dan penghargaan dari guru. Poin dan penghargaan yang diberikan oleh guru ini memacu semangat siswa untuk menjadi kelompok pemenang pada turnamen. Untuk dapat memenangkan turnamen, siswa harus dapat menjawab kartu soal yang diberikan oleh guru dan untuk itu siswa secara tidak langsung harus berkonsentrasi memahami materi pembelajaran yang dilakukan sebelum turnamen, sehingga akan memunculkan motivasi belajar dari dalam diri siswa.

Peningkatan hasil motivasi belajar ini sesuai dengan hasil penelitian dari Pranata (2012). Hasil penelitian ini menunjukkan peningkatan motivasi belajar siswa SMP N I Ngaglik Sleman pada mata pelajaran IPA dengan menerapkan model pembelajaran kooperatif tipe Teams Games Tournament (TGT). Peningkatan motivasi siswa ditunjukkan dengan adanya kenaikan persentase motivasi belajar siswa dari siklus I $(83,3 \%)$ ke siklus II (94\%).

Hal ini juga didukung oleh Sardiman (2008) bahwa ada beberapa contoh dan cara untuk menumbuhkan motivasi dalam kegiatan belajar di sekolah. Beberapa bentuk dan cara motivasi tersebut diantaranya (a) memberi angka; (b) hadiah; (c) saingan atau kompetisi; (d) ego-involvement; (e) memberi ulangan; (f) mengetahui hasil; (g) pujian; (h) hukuman; (i) hasrat untuk belajar; (j) minat; (k) tujuan yang 
diakui.

Berdasarkan pembahasan diatas, dapat diketahui bahwa peningkatan hasil belajar siswa berbanding lurus dengan peningkatan motivasi belajar siswa. Jika motivasi belajar siswa tinggi maka hasil belajar siswa juga akan tinggi. Hal ini sesuai dengan teori bahwa hasil belajar yang dicapai siswa dipengaruhi oleh dua faktor utama, yaitu faktor yang datang dari diri siswa itu sendiri dan faktor dari luar yang berasal dari lingkungan (Sudjana, 2000). Faktor yang datang dari diri siswa sendiri meliputi kecerdasan, sikap, kebiasaan, minat, kebutuhan, motivasi dan emosi. Motivasi merupakan faktor penggerak maupun dorongan yang dapat memicu timbulnya rasa semangat dan juga mampu merubah tingkah laku manusia atau individu untuk menuju pada hal yang lebih baik untuk dirinya sendiri. Sardiman (2008) mendefinisikan motivasi sebagai keseluruhan daya penggerak di dalam diri siswa yang menimbulkan kegiatan belajar, yang menjamin kelangsungan dari kegiatan belajar dan yang memberikan arah pada kegiatan belajar, sehingga tujuan yang dikehendaki oleh subjek belajar itu dapat tercapai.

\section{Penutup}

Berdasarkan analisis dan pembahasan terhadap hasil penelitian yang dilakukan, dapat ditarik beberapa simpulan sebagai berikut : (1) Penerapan model pembelajaran kooperatif tipe Teams Games Tournament dapat meningkatkan motivasi belajar siswa kelas XII MIPA 3 SMA Negeri 3 Singaraja. Hal ini dapat dilihat dari data hasil observasi motivasi sebagai data primer dan angket motivasi siswa sebagai data sekunder. Data hasil observasi siklus I yaitu $68 \%$ siswa memiliki motivasi belajar yang tinggi dan meningkat pada siklus II sebesar $32 \%$ menjadi $100 \%$ siswa sudah menunjukkan motivasi yang tinggi. Data angket motivasi siswa pada siklus I yaitu $40 \%$ siswa memiliki motivasi yang tinggi dan meningkat pada siklus II dengan $72 \%$ siswa. (2). Penerapan model pembelajaran kooperatif tipe Teams Games Tournament dapat meningkatkan hasil belajar siswa kelas XII MIPA 3 SMA Negeri 3 Singaraja. Hal ini dapat dilihat dari data hasil hasil belajar siswa pada siklus I dan siklus II. Hasil belajar siswa siklus I, 64\% siswa tuntas belajar dan $16 \%$ siswa belum tuntas belajar. Pada siklus II terjadi peningkatan sebesar $20 \%$ menjadi $84 \%$ siswa tuntas belajar dan hanya $16 \%$ siswa belum tuntas belajar.
Arikunto, Suharsimi. 1997. Dasar-dasar Evaluasi Pendidikan. Jakarta: Bumi Aksara.

Arikunto, S. (2008). Penelitian Tindakan Kelas. Jakarta: Bumi Aksara.

Asma, Nur. 2006. Model Pembelajaran Kooperatif. Departemen Pendidikan Nasional Direktorat Jendral Pendidikan Tinggi. Jakarta.

B.Uno, Hamzah. 2008. Model Pembelajaran. Jakarta: Bumi Aksara.

Depdiknas. 2006. Permendiknas No 22 Tahun 2006 Tentang Standar Isi. Jakarta : Depdiknas.

Dimyati dan Mudjiono, 2002. Belajar dan Pembelajaran.Jakarta: Rineka Cipta.

E. Mulyasa. (2006). Menjadi Guru Profesional Menciptakan Pembelajaran Kreatif dan Menyenangkan. Bandung: Remaja Rosdakarya Offset.

E. Mulyasa. 2008. Menjadi Guru Profesional Menciptakan Pembelajaran Kreatif dan Menyenangkan. Bandung : PT. Remaja Rosdakarya.

Huda, Miftahul. 2011. Cooperative Learning. Yogyakarta : Pustaka Belajar.

Isjoni, H. 2011. Pembelajaran Kooperatif Meningkatkan Kecerdasan Komunikasi Antara Peserta Didik. Yogyakarta: Pustaka Pelajar.

Pranata, Calissa Ari. 2012. Penerapan Model Pembelajaran Kooperatif Tipe TeamsGames-Tournament (TGT) Untuk Meningkatkan Motivasi Dan Hasil Belajar IPA Di SMP N 1 Ngaglik Sleman. http://eprints.uny.ac.id . diakses pada tanggal 27 oktober 2016 pukul 21.00 WITA.

Purwanto, Ngalim. 2008. Prinsip - prinsip dan teknik evaluasi pengajaran. Bandung : PT Remaja Rosdakarya.

Riduwan. 2012. Skala Pengukuran VariabelVariabel Penelitian. Bandung: CV Alfabeta.

Ramadhani, Dwi Windiani dkk. 2014. Penerapan Model Kooperatif Tipe Teams Games Tournament (TGT) dengan Pendekatan Saintifik Untuk Meningkatkan Hasil Belajar Kimia Siswa di Kelas X7 MAN 1 Model Kota Bengkulu. http://repository.unib.ac.id. diakses pada tanggal 27 oktober 2016 pukul 21.30 WITA.

Ahmad Rohani dan Abu Ahmadi. 2007. Pengelolaan Pengajaran. Jakarta: Rineka Cipta.

Sardiman. 2008. Interaksi dan Motivasi Belajar - Mengajar. Jakarta : PT Raja Grafindo Persada.

Slavin, Robert E. 2005. Cooperative Learning:

\section{Daftar Pustaka}


Teori, Riset dan Praktik. Bandung: Nusa Media.

Sudjana, Nana. 2000. Dasar - Dasar Proses Belajar Mengajar. Bandung : PT Sinar Baru Algensindo

Sudjana, Nana dan Ahmad Rivai. 2007. Teknologi pengajaran . Bandung : Sinar Baru Algesindo.

Sugiyono. 2010. Metode Penelitian Pendidikan Pendekatan Kuantitatif, Kualitatif, dan R \& D. Bandung: Alfabeta.

Suprijono, Agus. 2009. Cooperative Learning : Teori dan Aplikasi PAIKEM. Yogyakarta : Pustaka Belajar.

Suprijono, Agus. 2010. Cooperative Learning. Surabaya : Pustaka Pelajar.

Supriyadi, Dedi. 2005. Membangun Bangsa melalui Pendidikan. Bandung: Remaja Rosdakarya

Taniredja,Tukiran dkk. 2012. Model - model Pembelajaran Inovatif. Bandung: Alfabeta

Trianto. 2010. Mendesain Model Pembelajaran Inovatif-Progresif. Jakarta : Kencana Prenada Media Group.

Winkel. 1983. Psikologi Pendidikan dan Evaluasi Belajar. Jakarta : Gramedia 